\title{
Aligning Military and Soldiers' Values Hierarchy
}

\author{
Kamarul Zaman Ahmad (Corresponding author) \\ Faculty of Business \& Accountancy, University of Malaya \\ Kuala Lumpur, Malaysia \\ E-mail: drkamphd@yahoo.com \\ Mej Azlan Muhammad \\ Malaysian Armed Forces, Kuala Lumpur, Malaysia \\ E-mail:kzahmad@um.edu.my \\ Mej Zunaidi Hassan \\ Malaysian Armed Forces, Kuala Lumpur, Malaysia
}

\begin{abstract}
Studies on the fit between the person and the environment i.e. P-E fit are widespread. One aspect of P-E fit is values congruence i.e. the fit or similarity between the values of the organization and the employees' values. However, there has been no study that reported the congruence between an organization's value hierarchy (i.e. the ranking of its values) and those of its employees. This study investigates the values hierarchy congruence between the Malaysian Armed Forces (MAF) and its soldiers and the relationship with satisfaction. A sample of 214 officers in the MAF were obtained. When the top 5 values were used in analyses, values hierarchy congruence scores were significantly correlated with soldiers' satisfaction $(.122, \mathrm{p}<0.05)$. This suggests that not only should the values of the soldiers and the organizations be similar or congruent, but the priority or ranking of these values are important as well.
\end{abstract}

Keywords: Values, Hierarchy, Soldiers, Military, Congruence, Satisfaction

\section{Introduction: Person-Environment Fit}

Parsons' (1909) seminal work appears to be the first to have stressed the importance of both person and environment variables in vocational choice. Today, both variables are regarded as important. However, somewhere in between 1968 and 1989 (Mischel 1968; Pervin 1989), academics became divided. There were two extreme views. At one extreme, the view was that a person's behaviour was caused entirely by the "environment". At the other, the view was that the person's behaviour was determined solely by his "personality". Several theorists (e.g. Bowers, 1973; Endler \& Edwards, 1978) have argued that it is fruitless to argue that either personality or the situation is all-important.

P-E fit was summarised by Edwards (1996, p. 292) as follows: "In essence, P-E fit embodies the premise that attitudes, behaviour and other individual level outcomes result not from the person or environment separately, but rather from the relationship between the two (Lewin, 1951; Murray, 1938; Pervin, 1989)." There is an abundance of research on P-E fit. Buboltz, Ebberwein, Watkins and Savickas (1995) discovered that in the last 20 years preceding their article, a total of 229 articles on P-E fit appeared in the Journal of Vocational Behavior and 75 articles on it appeared in the Career Development Quarterly. They also noted that, about 63 of the 229 articles on P-E fit in the Journal of Vocational Behavior and 22 out of the 75 in the Career Development Quarterly appear during the last five years preceding their article. In addition, there are other studies involving P-E fit (cited below) reported in other journals. The concept of P-E fit has been described as, "so pervasive as to be one of, if not the dominant conceptual forces in the field" (Schneider, 2001, p.142). This constitutes evidence that the subject matter of P-E fit has not only been well established and extensively researched, but also remains a current area of interest. A review of the studies of P-E fit revealed that prior to 1987, most studies did not distinguish between the different forms of fit and did not expressly state which category of fit they were investigating. Kristof $(2005,1996)$, Piasentin and Chapman (2006) and Verquer, Beehr and Wagner (2003) have done a thorough literature review and as such, the bulk of it will not be reproduced here.

Kristof (1996) appears to be the first to categorise the different levels of fit. They are: 1) person-organisation fit or P-O fit i.e. the fit between the person and the organisation, (2) person-group fit or P-G fit i.e. the fit between the person and 
the group, and (3) person-job fit or P-J fit i.e. the fit between the person and the job. Research that involved comparing the values of the organization with the employees' values were P-O fit studies.

\section{Contribution of the Study}

Although there have been many studies on P-O fit i.e. value congruence, there has been no reported study that investigated the congruence between an organization's value hierarchy (i.e. the ranking of its values) and those of its employees, especially in the Military. What is unique in the Malaysian Armed Forces (MAF) which is absent in most other private and public organizations in Malaysia is the arrangement of values according to a certain order or hierarchy. The MAF spends a lot of time and effort in ensuring that its soldiers share the same values hierarchy as that of the organization. Thus, the main research question that this study aims to address is "Are soldiers whose value hierarchies more similar to those of the MAF, more satisfied?"

\section{Values}

Value can be defined as the fundamental belief behind attitudes or the rationale behind an action as a result of the importance that an individual or society has placed on it. As such values reflect a person's sense of right or wrong or what it ought to be (Jacobs, Flinks \& Schuchman, 1962). Scott (1956) defined values as a conception of what are desirable, thus influencing decisions and actions. Rokeach (1968) took this definition further by categorizing values into two categories i.e. terminal and instrumental values. Terminal values were described as the end states of idealized existence (e.g. wisdom, comfort, wealth) while instrumental values are the means for achieving the end states (e.g. learning, hardworking, thrift). However, this way of looking at values is not appropriate for organizations (especially government organizations) which often continue to exist long after the resignation, retirement and even the death of their employees.

\section{Military Values as Compared with Other Organizations' Values}

Jamieson and O'Mara (1991) listed nine of the top values based on a nationwide sample of managers and human resource professionals. They are: recognition for competence and accomplishments, respect and dignity, personal choice and freedom, involvement at work, pride in one's work, lifestyle quality, financial security, self-development and lastly, health and wellness. Military values on the other hand are different. According to the Value and Standards of the British Army (2008), the essential function of an armed force is to fight in battle. The same goes for the MAF. The military values have been inculcated in all soldiers during basic training and further enhanced while the soldier continues to work in the regiment or the unit where he is posted. Therefore all military personnel are known for their discipline and esprit de corps. Ethos and values are believed by the Malaysian army to be essential factors to produce an effective and efficient military organization. The military values was intended to unite and enhance individuals who come from different backgrounds, ethnicity, religion and cultures - and this is important in a multi-racial and multi-cultural country such as Malaysia. The esprit de corps is essential in critical moments on the battlefield.

\section{Value Congruence}

Krishnan (1996) and Kristoff (1996) defined person-organization congruence or P-O fit as the compatibility between people and organizations that occurs when they share similar fundamental characteristics - such as similar values. When there is a lack of fit or incongruence between the individuals' values and those of the organization, this may result in negative psychological, physiological and behavioral consequences (O'Reilly, Chatman \& Caldwell, 1991). Schneider (1987) popularized the Attraction-Selection-Attrition (ASA) theory, and one of the most important criteria is the value congruence.

\section{Job Satisfaction}

Job satisfaction represents a constellation of a person's attitudes towards or about a job as a whole. According to Smith, Kendall and Hulin (1969) it is a function of satisfaction with different aspects of the job which are the work itself, pay, opportunities for promotion, supervision and co-workers. This is the view adopted in this research. Comparison theories assess job satisfaction by asking workers how much of some characteristic (e.g. need, value, social comparisons) they have in their present jobs and how much of this characteristic they would like to have. According to Porter (1962), the larger the discrepancy between the amount of such characteristics that is present and the amount that is desired, the lower the reported job satisfaction. Conversely, it can be argued that the more similar the values of the person are to those of the organization, the higher the reported job satisfaction. There are already researchers that have investigated this (Meglino, Ravlin \& Adkins, 1989).

Some researchers have also found that certain values by themselves are related to satisfaction. Blood (1969) found that religious ethics (Protestant) have positive correlation with job satisfaction. This is supported by Yousef (2001) that religious values through work ethic have a positive relationship with work satisfaction. Therefore both research supports that religious values have a positive impact on work satisfaction and coincidentally, belief in God is also the 
number one value in the MAF. However, this research goes further by comparing the ranking of the values of the MAF with that of the soldiers and how the similarities in ranking are related to the job satisfaction of the soldiers.

\section{The Relationship between Value Congruence and Job Satisfaction}

Meglino, Ravlin and Adkins (1989) found that value congruence between the organization and the employees are related to satisfaction of the employees. Earlier research such as those by Schneider (1987) in his Attraction-Selection-Attrition (ASA) model, found that employees are choosing to work with the organizations which have similar values to them. This is supported by Chatman (1989) who found that employees are less satisfied when organizations have a different set of work values compared with theirs. This comes as no surprise as Locke (1976) has long argued that job satisfaction is related to how the organizational values or supports the needs of the employees. Fleishmen and Bass (1984) also argued that work satisfaction is achieved when the values and needs of the employees are fulfilled through the job. Pine and Innis (1987) pointed out that work values reflect the individual's needs and therefore have the potential to affect work outcomes and attitudes.

\section{Values Hierarchy Congruence}

Few research have been conducted in western countries such as United States of America and United Kingdom on the subject of military values hierarchy. Table 1 shows the values hierarchy in USA (United States Army, 2008), United Kingdom (British Army, 2008) and Malaysia (Malaysian Armed Forces, 1994).

\section{Insert Table 1}

The ranking of values of the Malaysian military are listed in Table 1 along with the values of other countries. They are:

1) Belief in God. This is the number one value which interestingly is completely absent from the military values of USA and UK. Belief in God entails the highest submission of man to the ascendency of the Creator. It is the principle that provides a sense of purpose to live, serve, fight and die for God and the country. History has proven that this belief made man willing to survive extreme hardship and even lay down their lives for a cause they believe in. Even though the soldiers are from different religions, they do believe in the existence of God as there are very few atheists (as found in our previous qualitative survey).

2) Discipline. This is the second Malaysian military value. It is the third ranked value in the UK military but is surprisingly missing in the USA military. Discipline is the prohibition of undesirable behaviour and the willingness to follow orders issued by superiors. This is the result of years of training. Discipline is instilled and maintained as a feeling of pride in himself/herself, his/her unit and the MAF, rather than by fear of punishment.

3) Loyalty. This is the strong allegiance to the King, and the country and demanded from all soldiers. It is the number one value in the USA, fifth in the UK.

4) Sacrifice. This is the subordination of self for the benefit of the superior, unit, army, king and country. Selfless-service is also ranked fourth in the USA. However, unlike selfless-service which is putting other people's needs ahead of our own, sacrifice may mean being willing to even lay down our lives for the greater good, when necessary.

5) Esprit de corps. This is the feeling of pride that goes along with the sense of belonging, fellowship and loyalty between comrades in the respective units. There is no room for individuality.

6) Integrity. This is akin to having moral principles, the ability to distinguish between right and wrong.

7) Courage. This is the high level of confidence built through the rigorous activities in training. Courage is also inspired by charismatic and effective leadership as well as devotion to one's religious beliefs.

James and Woodsmall (1988) in their book emphasized the importance of the values hierarchy i.e. the ranking order or priority of values, and how the values hierarchy of the organization must match the value hierarchy of the individual in order for the individual to achieve high performance and satisfaction. However, they have not done any empirical research to support this statement, thereby justifying this research. The current research examines the match or congruence between the hierarchies of the MAF with those of the soldiers and whether they are related to the satisfaction of the soldiers.

Accordingly the hypotheses are as follows:

$\mathrm{H} 0$ : There is no significant relationship between hierarchical value congruence scores and job satisfaction scores.

H1: Hierarchical value congruence scores are significantly related to job satisfaction scores.

\section{Method}

\subsection{Sample}

The sample consisted of 214 officers in the MAF from various locations throughout Malaysia. They were selected using judgmental or purposive sampling techniques from lists obtained from four separate army training centers - 44 
respondents were from the Institute of Management ("IPDA") and 25 were from the Senior Officer Institute ("INSPEKA"), both in the state of Negeri Sembilan, 20 respondents were from the Malaysian Staff College (MTAT) in the capital city of Kuala Lumpur, and 125 respondents were from the Army Combat Training Centre ("PULADA") in the state of Johor Bahru. The respondents were purposely chosen from these four institutions as it presents a convenient method to ensure that the sample consists of army officers who came from different regions in Malaysia.

214 questionnaires were distributed of which all 214 were returned i.e. a response rate of $100 \%$. The questionnaires were distributed personally by the researchers by visiting respondents at their institutions - there were 4 separate institutions. Prior to answering the questionnaire, the respondents were explained by the researchers regarding the purpose of the survey and instructions were given as to how to answer the questionnaire. The respondents were assured that their individual responses would be kept confidential and were requested to be as honest as possible when answering the questions. Respondents were given 30 minutes to complete the questionnaire in a room free from noise and distraction. Any queries regarding the questionnaires were explained on the spot and the questionnaires were then collected personally by the researchers after completion.

\subsection{Measures}

Part A collected demographic information of the participants. In part B, respondents were asked to rate the importance of the seven Malaysian Military Values on a 20-point scale ( 1 for "not important to me" and 20 for "very important to me"). This is to prevent any bias on the part of the respondents i.e. the temptation to recall the ranking as stipulated by the MAF and simply reproducing the same hierarchy in their answers. The method employed to calculate the value congruence scores is explained in the results section. Part C contained the Job Descriptive Index (JDI) which had a cronbach reliability score of 0.89 in this study.

Smith Kendall and Hulin (1969) developed the JDI, which is a simple short questionnaire that requires low verbal measures and is suitable for a wide variety of situations. The JDI uses 72 adjectives or items to describe the five dimensions of job satisfaction as follows: work (18 items), pay (9 items), promotion (9 items), supervision (18 items) and co-workers (18 items). Respondents were required to answer either "Yes", "No", or "?" for each adjective. The respondent was not asked how satisfied he/she was with his/her work but rather to describe his/her work i.e. the responses are a "job-referent" rather than "self-referent". Scoring for the questionnaire has been done in accordance with Smith et al's (1969) recommendation as follows: a positive answer to a positive item is scored 3; a negative answer to a negative item is scored 3; an undecided answer to any item is scored 1; a positive answer to a negative item is scored 0 and; a negative answer to a positive item is scored 0 . Note: an undecided answer scores 1 point, not 2, because Smith et al (1969) stated that a "?" is more indicative of dissatisfaction than satisfaction. This aspect was tested by Hanisch (1992) and shown to be correct. Total job satisfaction was obtained by simply summing up the results of the five facet scales to obtain an acceptable measure of global job satisfaction as was done by Hulin, Drasgow, and Komocar (1982).

There were several reasons why the JDI was selected for use in this study. The JDI has been reported to be the most frequently used measure of job satisfaction (De Meuse, 1986; O'Connor, Peters and Gordon, 1978; Yeager, 1981; Ironson et al, 1989). According to Ironson et al (1989), the Social Science Citation Index and Psychological Abstracts revealed 454 articles referring to the JDI between January 1979 and November 1987. The JDI was shown to have dimensional consistency over a wide range of situations (Jung, Dalessio and Johnson, 1986) and to have good discriminant and convergent validity. It has also been used in P-E fit studies to measure job satisfaction (Smart, Elton and McLaughlin, 1986). It has been shown to be reliable and valid not only in America but also in Spain (Hulin, Drasgow and Komocar, 1982), Saudi Arabia (Maghrabi and Johnson, 1995), Hong Kong (Lam, 1995) and Singapore (Goh, Koh and Low, 1991).

\section{Results}

\subsection{Descriptives}

Part A of the questionnaire collected information about the respondents' demographics (i.e. age, gender, job/education level). The ages ranged from 20 to 54 and the average age is 28.14 respondents $(6.5 \%)$ were aged between 20 to 25 years. The majority i.e. 96 respondents $(44.9 \%)$ were between 26 to 30 years. 51 respondents $(23.8 \%)$ were between 31 to 35 years, 17 respondents $(7.9 \%)$ were between 41 to 45 years, and 4 respondents (1.9\%) were above 46 years of age. The majority of the respondents were not married $(\mathrm{n}=181,84.6 \%)$ and the remaining were married $(\mathrm{n}=33,15.4 \%)$. As for gender, the majority of the respondents were male $(\mathrm{n}=190,88.8 \%)$ and the remaining were females $(\mathrm{n}=24,11.2 \%)$. This was expected as the Malaysian Army is a male dominated occupation. 72 respondents (33.6\%) had only school education, 66 respondents $(30.8 \%)$ had diplomas, 58 respondents $(27.1 \%)$ had undergraduate university degrees and 58 respondents $(27.1 \%)$ had Masters Degrees. In terms of salary, most of the respondents $(n=92,43 \%)$ had salary between RM2, 001 to RM3,000. The second largest category of respondents $(n=84,39.3 \%)$ had salaries from RM3,001 to RM4,000 (RM3.5 is approximately equivalent to 1 US dollar). In terms of years of service, most of the respondents 
$(\mathrm{n}=82,38.3 \%)$ had between 5 to 9 years. The second largest category of respondents $(\mathrm{n}=66,30.8 \%)$ had between 10 to 14 years.

\subsection{Calculation of the hierarchical value congruence scores}

The scores of the respondents in Part B of the questionnaire were transformed into rankings which were then compared with the rankings of the MAF and a hierarchical value congruence score was computed using a method loosely adapted from Meir, Hadas and Noyfeld (1997) (i.e. a study that obtained personality congruence scores by comparing the personality of each soldier with that of his team in the Israeli tank units). The step-by-step description of the procedure, is as follows: for each respondent, the value with the highest score was given the number one ranking, the value with the second highest score was given the number two ranking and so on until the seventh ranked value was identified. The value ranking or hierarchies of the respondents were then compared with the MAF value ranking. So, if the number one value of the respondent is belief in God (which is the same as the MAF value ranking) then, a score of 1 was given to a new variable which was formed and called "value congruence 1". If "belief in God" was the respondent's number 2 value, then a score of 2 was given to the said variable. If belief in God is the respondent's number 3 value, then the score of 3 was given to the said variable, and so on.

Next the second military value of "discipline" was examined. So, if the respondent's 2nd value was also discipline, then a score of 1 was given to a new variable formed called "value congruence 2". If the respondent's value of discipline was ranked 1 st or $3 \mathrm{rd}$, then a score of 2 was awarded to the said variable. If the respondents value of discipline was ranked 4 th, then a score of 3 was awarded and so on.

The third, fourth, fifth, sixth and seventh military values were also examined in a similar way and new variables were formed called "value congruence 3", "value congruence 4", "value congruence 5", "value congruence 6" and "value congruence 7" respectively. The scores from "value congruence 1" to "value congruence 7" were summed up to obtain a new variable called "total value congruence scores."

\subsection{Spearman correlations of hierarchical value congruence scores with JDI scores}

According to Zikmund (2003, p. 506), "ordinal scales typically use nonparametric statistical tests." Thus, tests of spearman correlation were conducted between "total value congruence scores" which were ordinal, and total JDI scores (i.e. total job satisfaction scores). However, contrary to expectation, the correlations were not significant at the 0.05 level. One interpretation could be that not all the 7 ranked values were important. In fact, James and Woodsmall (1988) argued that the congruence between the individuals' and the organization's values are more important for the higher ranked values than for the lower ranked ones. Thus, further analyses were done as follows: total value congruence scores were obtained in relation to only the top 6 military values and whether they are congruent with the respondents' top 6 values - a new variable called "total value congruence top 6" was formed. Again, correlations were not significant. Finally, total value congruence scores were obtained in relation to only the top 5 military values and whether they are congruent with the respondents' top 5 values - a new variable called "total value congruence top 5" was formed. This time, there was a significant correlation between this variable and job satisfaction scores $(.122, \mathrm{p}<.05)$. Thus, although the correlation was somewhat weak, hypothesis H1 was supported. This also supports James and Woodsmall's (1988) proposition that congruence of the higher ranked values are more relevant and important to the person than congruence of the lower ranked values. Details of the correlation coefficients and their significance level are stated in Table 2.

\section{Insert Table 2}

\section{Conclusion}

This study further developed the value congruence theory of P-O fit by examining not only the values congruence but the congruence in the ranking or hierarchy of values between the soldiers and the military organization. The MAF presented us with a unique opportunity to do this because most organizations do not rank their values but merely state them. This study lends support for the argument put forward by James and Woodsmall (1988) that it is important to align the hierarchy of values of the employees with those of the organization. Thus, the MAF is justified in taking the time and effort to this end.

This study also lends support for James and Woodsmall's (1988) argument that the top five values are more important than the lower ranked values - when the top 7 and top 6 values were taken into account, the correlations were not significant. However, when only the top 5 values were used to compute value congruence, the correlations with soldiers' job satisfaction were significant. Thus, MAF should focus on building only the top 5 military values as these are significantly related to job satisfaction.

\section{Limitations}

As with all studies, this one is also not without limitations. Limited sample size and cross sectional data are obvious limitations. Perhaps the most important limitation in this study was that the soldiers were not allowed to write down 
their own sets of values but were asked to rate the importance to them of each of the listed military values. So, perhaps if the respondents were allowed to list their own hierarchy of values, it is possible that they have their own unique sets of values, none of which contain any of the military values. It is possible that this could be the cause of the low correlations. The reason why this method was not used was because a pilot test was conducted during the early stages of questionnaire development, and of the ten people tested most of them did not include all the military values - some even had none. This would make computation of value congruence, even more complicated, and this approach was therefore not adopted. Despite this limitation, one could still advocate that the MAF should not only ensure that the soldiers have the same values as that of the military, but also in the same hierarchy, as results suggest that this would lead to greater satisfaction.

\section{References}

Blood, M. R. (1969). Work value and job satisfaction. Journal of Applied Psychology, 53(6), 456-459.

Bowers, K. (1973). Situationism in psychology: an analysis and critique. Psychological Review, 80, 307-36.

British Army. (2008, November 16). Values and Standards of the British Army. [Online] Available: $\mathrm{http} / / /$ www.army.mod.uk/documents/general/v_s_of_the_british_army.pdf+Values + and + Standards + of + the + British $+\mathrm{Ar}$ my\&cd $=1 \& h l=e n \& c t=c l n k \& g l=m y$

Buboltz, W. C., Ebberwein, C., Watkins, C. E., \& Savickas, M. L. (1995). A comparison of the content, authors and institutions represented in the Career Development Quarterly and the Journal of Vocational Behavior. Journal of Vocational Behavior, 46, 216-226.

Chatman, J. A. (1989). Improving international organizational research: a model of person-organization fit. Academy of Management Review, 14, 333-348.

De Meuse, K. P. (1986). A compendium of frequently used measures in industrial/organizational psychology. The Industrial-Organizational Psychologist, 23(2), 53-59.

Edwards, J. R. (1996). An examination of competing versions of the person-environment fit approach to stress. Academy of Management Journal, 39(2), 292-339.

Endler, N. S., \& Edwards, J. (1978). Person by treatment interactions in personality research. In Pervin L. A. \& Lewis, M. (Eds.), Perspectives in Interactional Psychology. New York: Plenum.

Fleishmen, B. A., \& Bass, A. R. (1984). Studies in Personnel and Industrial Psychology. Illnois: Dorsey Press.

Goh, C. T., Koh, H. C., \& Low, C. K. (1991). Gender effects on the job-satisfaction of accountants in Singapore. Work and Stress, 5(4), 341-348.

Hanisch, K. A. (1992). The Job Descriptive Index revisited: questions about the question mark. Journal of Applied Psychology, 77(3), 377-382.

Hulin, C. L., Drasgow, F., \& Komocar, J. (1982). Applications of item response theory to analysis of attitude scale translations. Journal of Applied Psychology, 67(6), 818-825.

Ironson, G. H., Brannick, M. T., Smith, P.C., Gibson, W. M., \& Paul, K. B. (1989). Construction of a job in general scale: comparison of global, composite and specific measures. Journal of Applied Psychology, 74(2), 193-200.

Jacob, P. E., Flink, J. J., \& Schuchman, H. L. (1962). Value and their function in Decision. American Behavior Scientist, 6-38.

James, T., \& Woodsmall, W. (1988). Time Line Therapy and the Basis of Personality. CA: Meta Publications.

Jamieson, D., \& O’Mara, J. (1991). Managing Workforce 200. San Francisco: Jossey-Bass.

Jung, K. G., Dalessio, A., \& Johnson, S. M. (1986). Stability of the factor structure of the Job Descriptive Index. Academy of Management Journal, 29(3), 609-616.

Krishnan, V. R. (1996). Value Systems of Transformational Leaders and the Relationship between Transformational Leadership and Value System Congruence of Subordinates. Unpublished Dissertation, Temple University, Philadelphia.

Kristof, A. (1996). Person-organisation fit: an integrative review of it's conceptualisations, measurement, and implications. Personnel Psychology, 49, 1-49.

Kristof, A., Zimmerman, R. D., \& Johnson, E. C. (2005). Consequences of individuals' fit at work: a meta-analysis of person-job, person-organization, person-group and person-supervisor fit. Personnel Psychology, 58, 281-342.

Lam, S. K. (1995). International Journal of Management, 12(1), 96-101.

Lewin, K. (1951). Field Theory in Social Science. New York: Harper. 
Locke, E. A. (1976). The nature and causes of job satisfaction. In Dunnette, M. D. (Ed.), Handbook of Industrial and Organizational Psychology (pp.1297-1349). Skokie, IL: Rand McNally.

Maghrabi, A. S., \& Johnson, D. A. (1995). An Arabic version of the revised Job Descriptive Index. Current Psychology, 14(1), 47-53.

Malaysian Armed Forces. (1994). The Malaysian Armed Forces Manual. Kuala Lumpur, Malaysia: Malaysian Armed Forces.

Meglino, B. M., Ravlin, E. C., \& Adkins, C. L. (1989). A work values approach to corporate culture: A test of the value congruence process and its relationship to individual outcomes. Journal of Applied Psychology, 74, 424-432.

Meir, E. I., Hadas, C., \& Noyfeld, M. (1997). Person-environment fit in small army units. Journal of Career Assessment, 5, 21-29.

Mischel, W. (1968). Personality and Assessment. New York: John Wiley \& Sons.

Murray, H. A. (1938). Explorations in Personality. Boston: Houghton Mifflin.

O’Connor, E. J., Peters, L. H., \& Gordon, S. M. (1978). The measurement of job satisfaction: current practices and future considerations. Journal of Management, 4, 17-26.

O’Reilly, C. A., Chatman, J., \& Caldwell, D. (1991). People and Organizational Culture: A Q-sort approach to assessing person-organizational fit. Academy of Management Journal, 34, 487-516.

Parsons, F. (1909). Choosing a Vocation. Boston, MA: Houghton Mifflin.

Pervin, L. A. (1989). Persons, situations, interactions: the history and a discussion of theoretical models. Academy of Management Review, 14(3), 350-360.

Piasentin, K. A., \& Chapman, D. S. (2006). Subjective person-organisation fit: Bridging the gap between conceptualisation and measurement. Journal of Vocational Behaviour, 69, 202-221.

Pine, G. J., \& Innis, G. (1987). Cultural and individual work value. Career development Quarterly, 35(2), 279-287.

Porter, L. W. (1962). Job attitudes in management: perceived deficiencies in need fulfilment as a function of job level. Journal of Applied Psychology, 46, 375-384.

Rokeach, M. R. (1968). The Nature of Human Value. New York: The Free Press.

Schneider, B. (1987). The people make the place. Personnel Psychology, 40, 437-454.

Schneider, B. (2001). Fits about fit. Applied Psychology: An International Review, 50, 141-152.

Scott, W. (1956). Values and Organization II. Chicago: Rand McNally.

Smart, J. C., Elton, C. F., \& Mclaughlin, G. W. (1986). Journal of Vocational Behavior, 29, 216-225.

Smith. P. C., Kendall L. M., \& Hulin, C. L. (1969). The Measurement of Satisfaction in Work and Retirement: A Strategy for the Study of Attitudes. Chicago: Rand McNally \& Company.

United States Army. (2008, November 16). Corps of Discovery. United States Army. [Online] Available: http://www.history.army.mil/lc/the\%20mission/the_seven_army_values.htm

Verquer, M. L., Beehr, T. A., \& Wagner, S. H. (2003). A meta-analysis of relations between person-organization fit and work attitudes. Journal of Vocational Behaviour, 63, 473-489.

Yeager, S. J. (1981). Dimensionality of the Job Descriptive Index. Academy of Management Journal, 24, 205-212.

Yousef, D. A. (2001). Islamic work ethic - A moderator between organizational commitment and job satisfaction in a cross-cultural context. Personnel Review, 30(2), 152-161.

Zikmund, W. G. (2003). Business Research Methods. South-Western: Thomson. 
Table 1. Comparison of military values hierarchy between different countries

\begin{tabular}{llll}
\hline Ranking & USA & United Kingdom & Malaysia \\
\hline 1 & Loyalty & Selfless commitment & Belief in God \\
\hline 2 & Duty & Courage & Discipline \\
\hline 3 & Respect & Discipline & Loyalty \\
\hline 4 & Selfless Service & Integrity & Sacrifice \\
\hline 5 & Honor & Loyalty & Esprit de corps \\
\hline 7 & Integrity & Respect for others & Integrity \\
\hline
\end{tabular}

Table 2. Spearman Correlations between value hierarchy congruence scores and job satisfaction

\begin{tabular}{llll}
\hline & $\begin{array}{l}\text { Spearman correlation } \\
\text { with job satisfaction }\end{array}$ & Sig 2-tailed & Significance \\
\hline Top 7 values & .072 & .148 & Not significant \\
\hline Top 6 values & .048 & .243 & Not significant \\
\hline Top 5 values & $.122^{*}$ & .037 & Significant \\
\hline
\end{tabular}

$*=$ sig at the 0.05 level 